\title{
Pengembangan Aplikasi COSYCALSHIP Berbasis Android untuk Pengelolaan Beasiswa Menggunakan Metode Waterfall
}

\author{
Hendrawan Widianto, Annisa Putri Pratama, Ayu Prema Laksmi \\ Teknik Industri, Fakultas Teknologi Informasi dan Industri, Institut Teknologi Telkom Surabaya, \\ Jl. Ketintang No.156, Kota Surabaya, Jawa Timur 60231, Indonesia \\ hendrawan@student.ittelkom-sby.ac.id
}

\begin{abstract}
Abstrak
Banyaknya pemohon beasiswa dari kalangan mahasiswa menjadi tantangan bagi tiap instansi di Indonesia dengan skema beasiswa yang 'efektif' dan 'efisien'. Berdasarkan berita resmi Badan Pusat Statistik (BPS), perekonomian Indonesia mengalami penurunan sebesar 5,32\% dari triwulan ke-II 2019. Dilihat dari 17 sektor badan usaha, hampir semuanya mengalami penurunan termasuk sektor industri 6,19\% dan jasa pendidikan 1,21\%. Akan tetapi, di sektor informasi dan komunikasi masih mengalami pertumbuhan yang signifikan sebesar 10,88\%. Oleh karena itu, dalam penelitian ini, dikembangkan aplikasi COSYCALSHIP (Complete, Easy, Practical Scholarship), sebuah aplikasi berbasis android. Metode yang digunakan aplikasi adalah waterfall. Metode ini dipilih karena menggambarkan pendekatan yang sistematis dan berurutan. Hasilnya yaitu terciptanya sebuah aplikasi yang menyediakan informasi, tips dan trik mendapatkan beasiswa, klasifikasi pendaftar beasiswa serta pengontrolan terhadap mahasiswa penerima beasiswa yang dapat memberikan pelayanan terbaik bagi penggunanya, serta dapat mengatasi berbagai permasalahan yang dihadapi oleh mahasiswa dan instansi terkait pemanajemenan beasiswa.
\end{abstract}

Kata kunci: aplikasi, complete, easy, practical, scholarship

\section{Pendahuluan}

Seperti yang kita pahami saat ini, di berbagai institusi pendidikan tinggi di Indonesia (baik swasta maupun negeri) banyak sekali tersedia peluang beasiswa untuk mahasiswa yang berprestasi dan mahasiswa kurang mampu. Penyedia beasiswa sendiri tidak hanya dari perguruan tinggi negeri (PTN) maupun perguruan tinggi swasta (PTS), namun beberapa perusahaan swasta dan negeri yang besar juga menyediakan sejumlah skema beasiswa bagi para mahasiswa. Sebagaimana dalam UndangUndang Dasar 1945 pasal 31 (1) bahwa tiap-tiap warga negara berhak mendapatkan pengajaran. Pasal tersebut menjelaskan bahwa pemerintah pusat dan pemerintah daerah wajib memberikan layanan dan kemudahan serta menjamin terselenggaranya pendidikan yang bermutu bagi setiap warga negara tanpa diskriminasi. Penyelenggaraan pendidikan yang bermutu sendiri diperlukan biaya yang cukup besar, sehingga setiap peserta didik pada satuan pendidikan berhak mendapatkan biaya pendidikan atau beasiswa bagi mereka yang orangtuanya tidak mampu, dan bagi mereka yang berprestasi.

Pemerintah melalui Direktorat Jenderal Pendidikan Tinggi Departemen Pendidikan Nasional berupaya mengalokasikan dana untuk memberikan beasiswa kepada mahasiswa yang secara ekonomi tidak mampu untuk membiayai pendidikannya dan kepada mahasiswa yang memiliki prestasi dengan menyediakan Kartu Indonesia Pintar (KIP) kuliah dan menyediakan beasiswa LPDP untuk jenjang S2 dan S3. Anggaran untuk KIP kuliah sendiri yaitu sebesar Rp. 6,7 Triliun untuk 819,4 ribu mahasiswa dan Rp.1.8 Triliun beasiswa S2/S3 LPDP untuk 5000 mahasiswa baru dan 12.333 mahasiswa lanjutan (APBN, 2020). Walaupun dengan tersedianya KIP kuliah dan beasiswa LPDP, lulusan SMA/SMK tidak sebanding dengan daya tampung perguruan tinggi negeri maupun swasta. Jumlah lulusan SMA dan SMK sebanyak 2.997.421 juta siswa sedangkan penerimaan mahasiswa perguruan tinggi 
negeri/swasta berjumlah 1.732.308 juta (Kemenristekdikti, 2018). Jumlah lulusan SMA dan SMK yang mendekati 3 juta dan daya tampung perguruan tinggi hanya berkisar 1,8 juta, menyebabkan kurang lebih 1,2 juta siswa tidak dapat melanjutkan pendidikan ke perguruan tinggi, sehingga harus mencari pekerjaan. Namun mencari pekerjaan untuk lulusan SMA/SMK tidaklah mudah, sehingga dapat menyebabkan sebagian harus menjadi pengangguran. Saat ini, pengangguran terbanyak didominasi oleh siswa tamatan SMA/ SMK yang tidak dapat melanjutkan pendidikan ke jenjang perkuliahan. Pengangguran terbuka menurut pendidikan tertinggi yang ditamatkan pada tahun 2019 yaitu sebanyak 6.816 .840 juta pengangguran. Terdiri dari 35.655 belum pernah sekolah, 435.655 belum tamat SD, 954.010 tamatan SD, 1.219.767 tamatan SLTP/SMP, 1.680.794 tamatan SMA, 1.381.964 tamatan SMK, 269.976 lulusan Akademi/Diploma, dan 839.019 lulusan Universitas (Badan Pusat Statistik, 2019). Jumlah pengangguran tamatan SMA dan SMK yang begitu banyak menyebabkan bertambah pula peminat beasiswa agar dapat melanjutkan pendidikan ke perguruan tinggi.

Agar pelaksanaan pemberian beasiswa sesuai dengan prinsip 3T: yaitu Tepat sasaran, Tepat jumlah dan Tepat waktu, maka perlu adanya pengambilan keputusan yang tepat sehingga pelaksanaan beasiswa dapat tercapai dengan menetapkan prinsip $3 \mathrm{~T}$ tersebut. Pengambilan keputusan adalah pemilihan beberapa tindakan alternatif yang ada untuk mencapai satu dan beberapa tujuan yang telah ditetapkan (Turban, dkk. 2005).

Pada awal tahun 2020 Indonesia diserang oleh Coronavirus Disease 2019 (COVID-19) virus yang menyerang pada sistem pernapasan ini berdampak buruk dalam berbagai aspek kehidupan salah satunya pada aspek perekonomian Indonesia. Berdasarkan berita resmi Badan Pusat Statistik (BPS) yang disiarkan secara langsung melalui aplikasi zoom dan youtube pada Rabu, 5 Agustus 2020 dapat dilihat bahwa pertumbuhan perekonomian Indonesia pada tahun 2019-2020 semakin menurun. Pada triwulan kedua tahun 2020 jika dibandingkan dengan triwulan kedua tahun 2019 mengalami kontraksi sebesar 5,32\%. Kemudian jika dibandingkan lagi triwulan pertama tahun 2020 dengan pertumbuhan ekonomi Indonesia pada triwulan kedua ini juga mengalami kontraksi minus 4,19\% sementara nilai kumulatif semester 1 tahun 2020 terhadap semester 1 tahun 2019 mengalami kontraksi sebesar 1,2\%. Dengan terjadinya penurunan perekonomian Indonesia, tentu saja dapat mengancam pengalokasian dana untuk pemberian beasiswa.

Badan Pusat Statistik (BPS) melalui berita pertumbuhan ekonomi pada triwulan kedua tahun 2020 sementara menunjukkan dari 17 sektor yang ada hanya ada 7 sektor yang masih tumbuh tetapi lambat kecuali untuk sektor informasi dan komunikasi. Pada masa pandemi COVID-19 ini sektor informasi dan komunikasi tumbuh signifikan sebesar 10,88\%, dikarenakan selama pandemi COVID19 terjadi peningkatan belanja iklan televisi dan media digital, peningkatan trafik data penggunaan internet, peningkatan jumlah pelanggan penyedia jasa internet maupun TV. Sedangkan dalam bidang industri mengalami kontraksi 6,19\% dan dalam jasa pendidikan mengalami kontraksi sebesar 1,21\% (Badan Pusat Statistik, 2020).

Dengan semakin banyaknya permohonan beasiswa, ditambah lagi dengan terjadinya penurunan di berbagai sektor lapangan usaha, termasuk sektor industri dan jasa pendidikan maka secara otomatis distribusi dana CSR (Corporate Social Responsibility) dari perusahaan dan dana beasiswa yang akan dikeluarkan menjadi sesuatu hal yang krusial, sehingga distribusi harus tepat sasaran. Permasalahan tersebut menjadi tantangan tersendiri bagi pihak pengelola lembaga pendidikan khususnya universitas ataupun instansi lainnya agar dapat memberikan keputusan yang tepat dan efisien dalam mengelola data penerima beasiswa yang benar-benar berhak menerima beasiswa tersebut.

Saat ini pengelolaan beasiswa dari berbagai lembaga pendidikan ataupun instansi lainnya masih menggunakan cara manual untuk menentukan peserta yang berhak menerima beasiswa sehingga pengolahan dan penyimpanan data kurang efektif, membutuhkan waktu yang relatif lama dan sering terjadi subjektivitas dari para pengambil keputusan. Selain itu, tidak adanya pemantauan atau evaluasi lebih lanjut kepada penerima beasiswa oleh instansi, serta informasi mengenai beasiswa yang masih 
menyebar di berbagai media, menyebabkan para mahasiswa dari berbagai lembaga/instansi pendidikan sulit memperoleh informasi beasiswa. Berdasarkan berita resmi BPS, sektor yang mengalami pertumbuhan secara signifikan di masa pandemi COVID-19 adalah sektor informasi dan komunikasi. Hal tersebut kemudian membuka peluang bagi peneliti, praktisi, dan masyarakat luas untuk terus berpacu dalam pengembangan infrastruktur dan pemanfaatan teknologi informasi dan komunikasi (ICT). Berdasarkan kondisi-kondisi yang sudah diuraikan, salah satu solusi yang bisa ditawarkan ke masyarakat adalah pengembangan aplikasi COSYCALSHIP.

Aplikasi COSYCALSHIP (Complete, Easy, Practical Scholarship) merupakan aplikasi berbasis android yang dapat memberikan informasi beasiswa, tips dan trik untuk mendapatkan beasiswa, klasifikasi, pendataan dan pengontrolan terhadap penerima beasiswa sehingga mahasiswa dapat dengan mudah mendapatkan informasi mengenai beasiswa internal maupun eksternal, serta instansi/lembaga pendidikan dapat menyeleksi dan mengontrol penerima beasiswa dengan, cepat, tepat dan efisien. Metode yang digunakan selama tahap pengembangan aplikasi adalah metode waterfall. Waterfall merupakan salah satu metode pengembangan sistem informasi yang bersifat sistematis dan sekuensial, artinya setiap tahapan dalam metode ini dilakukan secara berurutan dan berkelanjutan (Nasution, 2012). Metode ini dipilih karena menggambarkan pendekatan yang sistematis dan berurutan sehingga dapat meminimalisir kesalahan yang akan terjadi pada saat proses pengembangan aplikasi COSYCALSHIP.

Tercatat beberapa peneliti telah menggunakan metode waterfall untuk pengembangan aplikasi. (Dermawan dan Hartini, 2017) mengembangkan sistem informasi aplikasi perhitungan nilai mata pelajaran berbasis web pada sekolah dasar Al-Azhar Syifa Budi Jatibening dengan menggunakan model atau metode waterfall yang mana didalamnya terdapat beberapa menu yang ditujukan bagi guru, wali kelas, dan juga admin yang ada di sekolahan tersebut. Ridho dan Soelistijadi (2019) membuat perancangan aplikasi pemesanan makanan ringan berbasis Object Oriented dengan metode waterfall. Dalam aplikasi tersebut terdapat menu-menu terkait detail produk, menu keranjang, menu pembayaran, serta menu kategori yang mana ditujukan untuk mempermudah kegiatan pemesanan bagi konsumen UD Enggal Jaya di Semarang. (Kustian, 2019) pemesanan tiket bus dengan menggunakan pengembangan aplikasi menggunakan metode waterfall dibuat oleh peneliti untuk mempermudah calon penumpang transportasi darat, bus, yang didalamnya juga terdapat beberapa fitur seperti menu pemesanan, dll. (Hardiyan, dkk., 2017) dengan judul penelitian 'Penerapan Model Waterfall pada Program Aplikasi Pengolahan Nilai Siswa Online di SMP Islam Abaabiyl Tangerang' diharapkan mampu memberikan kemudahan bagi pihak guru untuk mengolah data nilai siswa dengan beberapa fitur di dalamnya yang mempermudah proses perekapan nilai. (Silvi, dkk., 2018) perancangan sistem informasi aplikasi bantuan sosial berbasis android dengan menggunakan metode waterfall yang ditujukan bagi dinas sosial untuk mengefisiensikan proses distribusi bantuan agar tidak terjadi berbagai penyelewengan dan kecurangan oleh pihak yang tidak bertanggung jawab. Beberapa fitur menu-menu di dalamnya yaitu menu kategori bantuan, account, dan menu login.

Pengembangan aplikasi COSYCALSHIP berbasis android menggunakan metode waterfall ini dibuat sebagai sarana untuk memudahkan para mahasiswa dalam memperoleh berbagai informasi terkait beasiswa yang disebar di seluruh Indonesia, baik itu beasiswa internal maupun eksternal secara online. Pihak instansi sendiri dapat memanfaatkan aplikasi ini untuk mengelola dan mengontrol terkait pendataan, penyaluran, dan penetapan dana beasiswa yang akan diberikan nantinya. Pihak instansi akan lebih efektif dan efisien dalam pengelolaan data dan perkembangan pihak penerima beasiswa dan juga akan memberikan wawasan dan pengetahuan khusus di bidang informatika yang ada hubunganya dengan aplikasi-aplikasi online. Pemilihan metode waterfall dikarenakan metode ini menggambarkan pendekatan yang sistematis dan berurutan sehingga dapat meminimalisir kesalahan yang akan terjadi pada saat proses pengembangan aplikasi COSYCALSHIP. Berdasarkan uraian latar belakang, rumusan masalah yang dapat diambil dalam penelitian ini dapat dinyatakan sebagai berikut: 
"Bagaimana pengembangan aplikasi COSYCALSHIP berbasis android untuk pengelolaan informasi beasiswa dengan menggunakan metode waterfall.

\section{Metode Penelitian}

Metode yang digunakan dalam penelitian ini secara ringkas disajikan melalui flowchart pada gambar 1 di bawah ini.

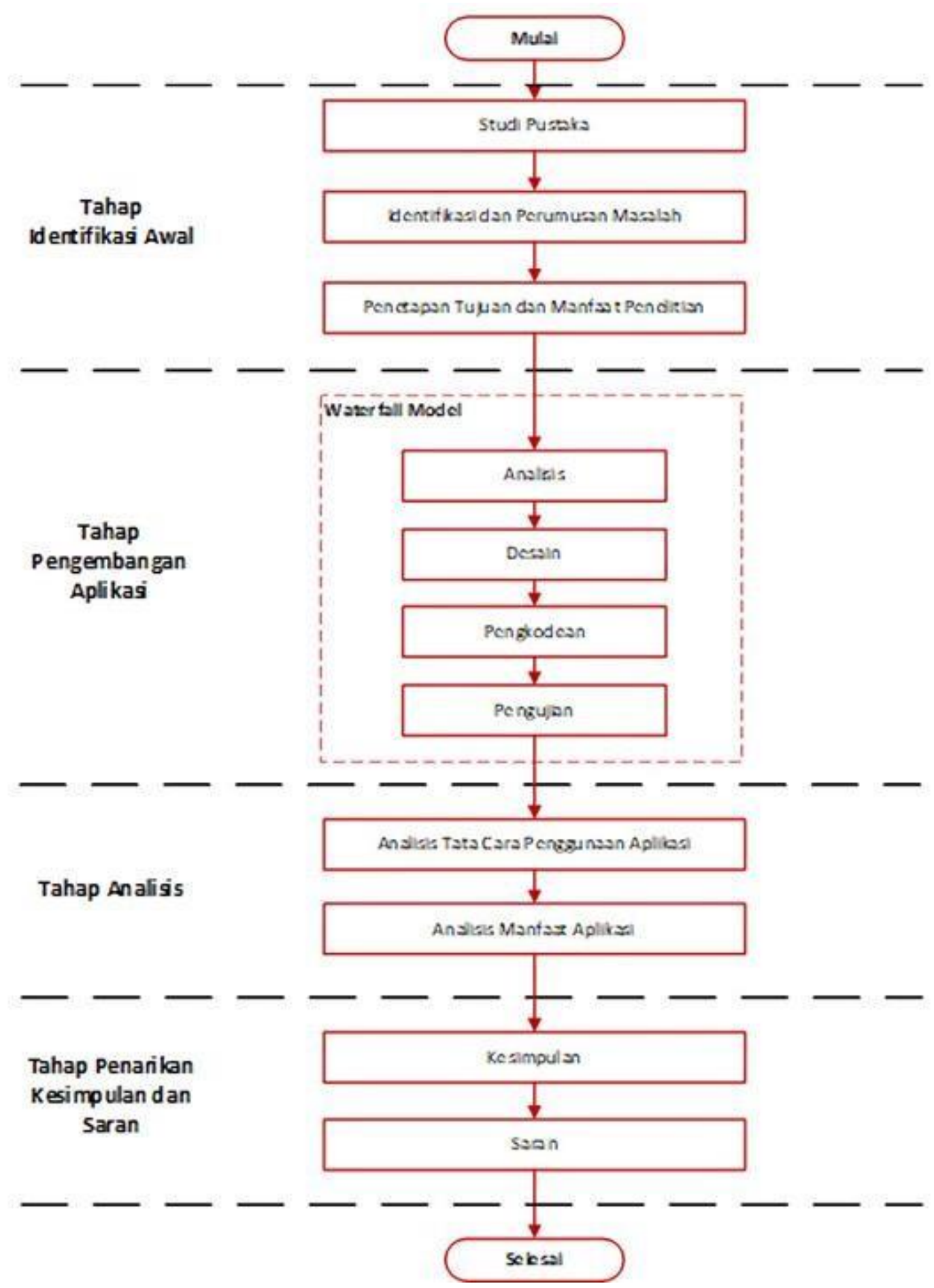

Gambar 1. Flowchart metode yang digunakan dalam penelitian.

Waterfall Model adalah proses pengembangan perangkat lunak tradisional yang umum digunakan dalam proyek sistem informasi dengan menggunakan moderator "Linear Sequential Model". Metode ini juga biasa disebut dengan "classic life cycle" dikarenakan metode waterfall menunjukkan sebuah pendekatan sistematis untuk pengembangan perangkat lunak (Pressman, 2010). 


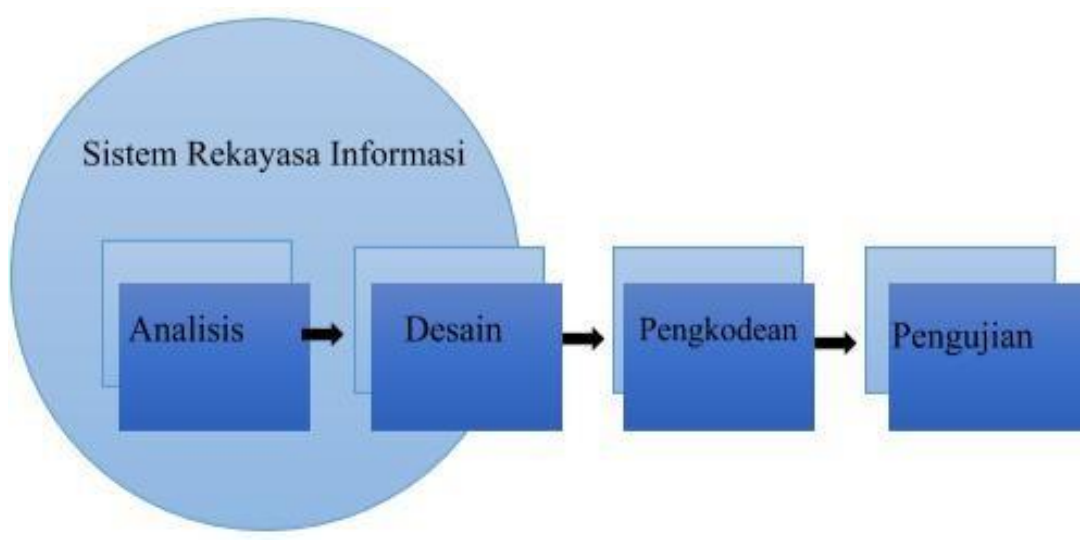

Gambar 2. Model Waterfall.

Seperti layaknya air terjun, tahapan dalam metode ini harus dilakukan secara sistematik dan berurutan, dimana setiap proses yang dilalui harus diselesaikan terlebih dahulu agar dapat melanjutkan ke tahapan selanjutnya. Tahapan-tahapan model waterfall (Sukamto dan Shalahudin, 2013) adalah:

1) Analisis Kebutuhan Perangkat Lunak

Tahapan ini bertujuan untuk menganalisis berbagai kebutuhan yang dibutuhkan dalam mengembangkan aplikasi COSYCALSHIP baik itu berupa data-data mahasiswa, instansi, maupun berbagai dokumen yang berisi informasi mengenai instansi penyediaan beasiswa, sehingga dapat meminimalisir permasalahan yang akan terjadi baik dari sisi user yang merupakan mahasiswa peminat beasiswa, ataupun admin sebagai instansi pemberi beasiswa.

2) Desain

Setelah menganalisis berbagai kebutuhan yang dibutuhkan, proses atau tahapan selanjutnya adalah desain aplikasi COSYCALSHIP. Tahapan ini lebih difokuskan pada pembuatan program, yang mencakup struktur data, tampilan aplikasi, hingga proses pembuatan kode program dalam aplikasi COSYCALSHIP. Tahapan desain juga merupakan penghubung antara tahapan analisis kebutuhan ke tahapan berikutnya yaitu pembuatan kode program.

3) Pembuatan Kode Program

Pembuatan kode program harus disesuaikan dengan hasil analisis kebutuhan dan desain yang telah dilakukan pada tahapan sebelumnya, sehingga Input dan Output yang dihasilkan dalam pengembangan aplikasi COSYCALSHIP yang berbasis mobile dapat diimplementasikan menggunakan pemrograman android dengan baik.

4) Pengujian

Pada tahapan ini, aplikasi COSYCALSHIP akan diuji dari segi fungsional dan logikanya, serta memastikan bahwa semua bagian dalam aplikasi COSYCALSHIP sudah diuji. Pengujian ini dilakukan untuk memastikan hasil dari aplikasi sesuai dengan yang diharapkan serta untuk meminimalisir kesalahan (error) yang dapat terjadi.

5) Pendukung (Support) atau Pemeliharaan (Maintenance)

Memelihara perangkat atau aplikasi yang telah dibuat adalah hal sangat penting, oleh karena itu pada tahapan ini penulis dianjurkan untuk mengupayakan pengembangan sistem secara maksimal agar aplikasi COSYCALSHIP dapat diimplementasikan dan berjalan dengan baik. Tahapan ini juga bisa disebut dengan tahapan perbaikan, dimana jika terdapat perubahan atau penambahan fitur pada saat pengembangan aplikasi, maka pada tahapan ini kita dapat mengulangi proses pengembangan aplikasi yang dimulai dari analisis hingga pemrograman tanpa harus membuat perangkat lunak baru.

Metode waterfall atau metode air terjun merupakan salah satu siklus hidup klasik dalam pengembangan perangkat lunak. Metode ini menggambarkan pendekatan yang cukup sistematis juga berurutan pada pengembangan software, mulai dari spesifikasi kebutuhan pengguna, perencanaan, 
pemodelan, konstruksi, penyerahan sistem ke pengguna, serta perawatan sistem. Model ini termasuk ke dalam model generic pada rekayasa perangkat lunak dan pertama kali diperkenalkan oleh Winston Royce sekitar tahun 1970 sehingga seringkali dianggap kuno, tetapi merupakan model yang paling banyak dipakai dalam Software Engineering (SE). Model ini melakukan pendekatan secara sistematis dan berurutan. Disebut dengan waterfall karena tahap demi tahap yang dilalui harus menunggu selesainya tahap sebelumnya dan berjalan berurutan. Beberapa kelebihan mengembangkan software dengan metode waterfall, antara lain:

a) Metode ini adalah model pengembangan yang paling handal dan paling lama digunakan oleh para developer.

b) Cocok untuk membuat software dengan skala besar.

c) Cocok untuk mengembangkan sistem yang bersifat generic.

d) Pengerjaan proyek sistem akan mudah dikontrol dan terjadwal dengan baik.

\section{Hasil dan Pembahasan}

\subsection{Analisis Kebutuhan Perangkat Lunak}

Aplikasi COSYCALSHIP (Complete, Easy, Practical Scholarship) merupakan aplikasi pengelolaan beasiswa oleh instansi pemberi beasiswa dan aplikasi penyedia informasi beasiswa bagi mahasiswa yang membutuhkan beasiswa dimana dalam aplikasi ini terdapat berbagai fitur yang dapat memudahkan instansi dalam pengelolaan beasiswa, serta memudahkan mahasiswa dalam memperoleh informasi tersedianya beasiswa. Dalam mengembangkan aplikasi ini dibutuhkan analisis kebutuhan perangkat lunak (aplikasi) terlebih dahulu. Analisa kebutuhan perangkat lunak ditujukan untuk mengumpulkan kebutuhan-kebutuhan dalam mengembangkan aplikasi COSYCALSHIP dan kemudian mentransformasikan ke dalam sebuah deskripsi yang jelas dan lengkap. Demi mempermudah dan menunjang distribusi layanan beasiswa ke mahasiswa di Indonesia dengan tepat, maka diperlukan sebuah aplikasi berbasis android yang mampu melayani mahasiswa dalam bidang beasiswa dan melayani pihak kesejahteraan mahasiswa di suatu instansi dalam manajemen dan monitoring distribusi beasiswa tersebut. Data-data yang dibutuhkan dalam mengembangkan aplikasi COSYCALSHIP yaitu sebagai berikut:

1) Nama mahasiswa

2) Nomor Induk Mahasiswa (NIM)

3) Asal institusi

4) Semester

5) Alamat tinggal

6) Pekerjaan orang tua mahasiswa

7) No. rekening mahasiswa

8) Surel

9) Indek Prestasi Kumulatif (IPK) mahasiswa

10) Pengalaman organisasi/pengabdian masyarakat

11) Prestasi juara 1, 2, dan 3 tingkat provinsi, nasional, dan internasional

12) Penghasilan orang tua mahasiswa

13) Anak dalam tanggungan orang tua mahasiswa

14) Penulisan esai mahasiswa

15) Informasi instansi penyedia beasiswa

16) Informasi mengenai tips dan trik untuk mendapatkan beasiswa 


\subsection{Design/Perancangan Sistem}

Tahap perancangan perangkat lunak (design) merupakan proses yang berfokus pada beberapa atribut yang ada di perangkat lunak. Proses ini menerjemahkan kebutuhan ke dalam sebuah model perangkat lunak dan berdasarkan analisis sistem sebelumnya menghasilkan rancangan yang berisi ERD (Entity Relationship Diagram), UML, dan desain antar muka. Entity Relationship Diagrams (ERD) adalah salah satu metode pemodelan perangkat lunak yang biasanya digunakan dalam tahap analisis perancangan basis data. ERD berupa model data konseptual yang merepresentasikan data tertentu. Tahap selanjutnya adalah membuat UML dengan membuat definisi aktor kemudian membuat activity diagram yang menghubungkan aktor dengan sistem.

\subsubsection{Deskripsi Aktor/Pengguna}

Terdapat tiga aktor atau pengguna yang menggunakan aplikasi COSYCALSHIP, yaitu bagian administrasi yang mengelola beasiswa dalam sebuah lembaga/instansi, mahasiswa dan super Admin. Deskripsi ketiga aktor tersebut dapat dilihat pada tabel 1 di bawah ini.

Tabel 1. Deskripsi Aktor

\begin{tabular}{|c|c|c|}
\hline No. & Aktor & Deskripsi \\
\hline 1. & $\begin{array}{l}\text { Admin (Bagian Administrasi } \\
\text { Sebuah Instansi) }\end{array}$ & $\begin{array}{l}\text { Orang yang bertugas dan memiliki hak akses untuk } \\
\text { melakukan pengelolaan beasiswa (penambahan, } \\
\text { pengontrolan, pencairan, penerimaan dll), melihat } \\
\text { informasi mahasiswa, mengelola seluruh data pendaftar } \\
\text { beasiswa, mengelola akun pribadi, mengelola berita } \\
\text { dan komentar, dan mengelola history system. }\end{array}$ \\
\hline 2. & Mahasiswa & $\begin{array}{l}\text { Orang yang berhak mendapatkan akses untuk mendapat } \\
\text { informasi tentang penyediaan beasiswa, tips dan trik } \\
\text { untuk mendapat beasiswa, serta dapat melakukan } \\
\text { pendaftaran beasiswa melalui aplikasi dengan } \\
\text { melengkapi dokumen yang dibutuhkan sebuah instansi } \\
\text { penyedia beasiswa }\end{array}$ \\
\hline 3 & Super Admin & $\begin{array}{l}\text { Orang yang bertugas dan memiliki hak akses untuk } \\
\text { melakukan pengelolaan terhadap sistem aplikasi } \\
\text { COSYCALSHIP serta mengelola dan mengontrol } \\
\text { aktivitas Instansi dan mahasiswa dalam } \\
\text { menggunakan aplikasi COSYCALSHIP. }\end{array}$ \\
\hline
\end{tabular}

\subsubsection{Activity Diagram}

Diagram ini akan menggambarkan hubungan antara ketiga aktor yaitu instansi, mahasiswa dan super admin dengan sistem dalam menggunakan dan mengelola aplikasi COSYCALSHIP.

Berdasarkan Gambar diagram activity ketiga aktor di atas, dapat kita lihat bahwa terdapat enam tahapan dalam diagram activity instansi, empat tahapan dalam diagram activity mahasiswa dan tiga tahapan dan diagram activity super admin. Tahapan dalam diagram activity instansi terdiri dari tahapan login pada menu instansi, pengisian data, pengisian data kualifikasi penerima beasiswa, pemeringkatan bagi pendaftar beasiswa, pemberitahuan kepada penerima beasiswa dan pengontrolan terhadap mahasiswa yang menerima beasiswa. Tahapan dalam diagram activity mahasiswa yaitu tahapan login pada menu mahasiswa, pendaftaran beasiswa, pengumuman hasil pendaftaran dan edukasi untuk mendapatkan beasiswa. Tahapan dalam diagram activity super admin yaitu tahapan 
mengelola, mengontrol dan memperbaiki kesalahan dalam aktivitas instansi, mahasiswa dan sistem secara keseluruhan.
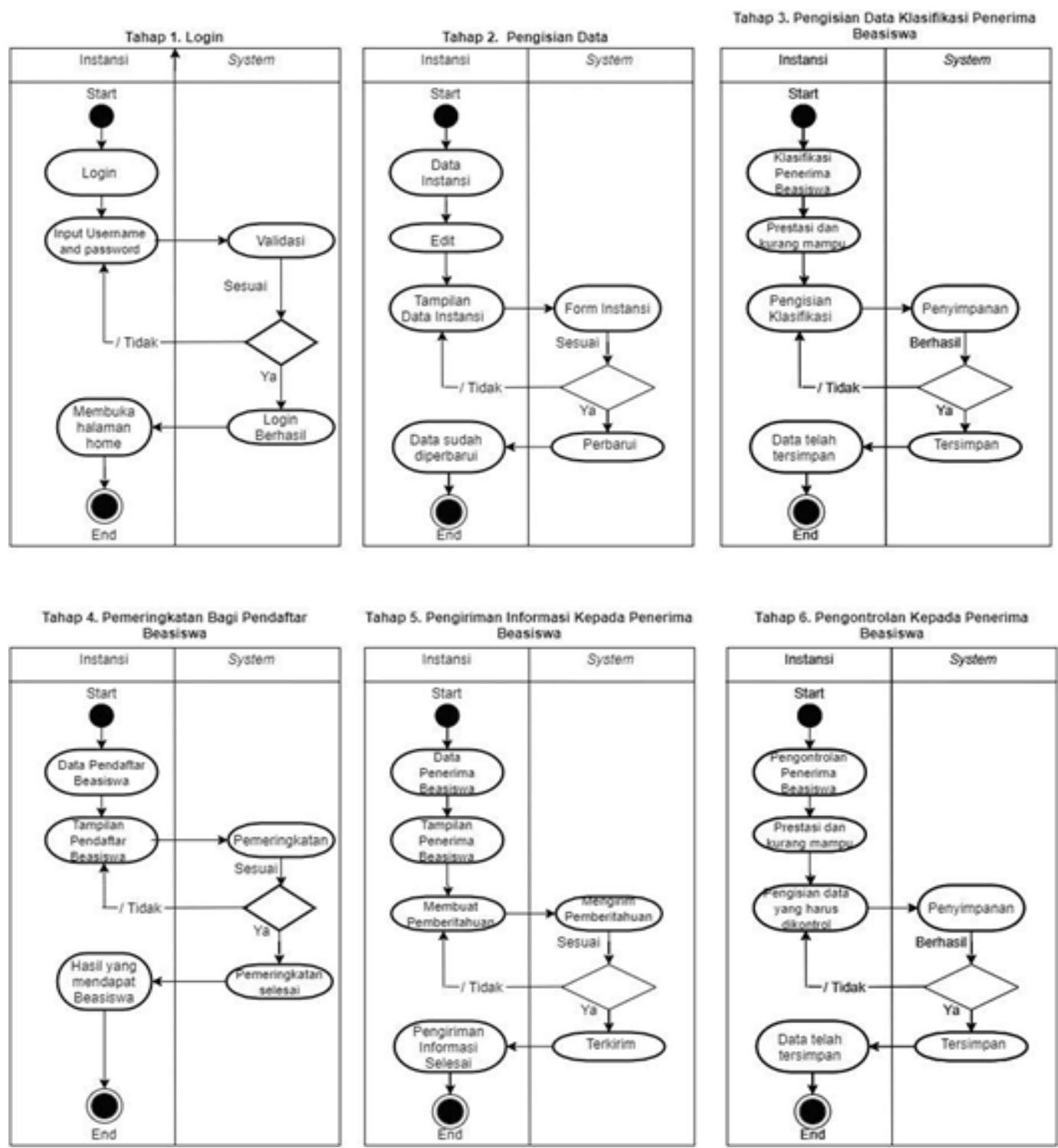

Gambar 3. Diagram Activity Instansi 
Journal of Advances in Information and Industrial Technology (JAIIT), Vol. 2, No. 2

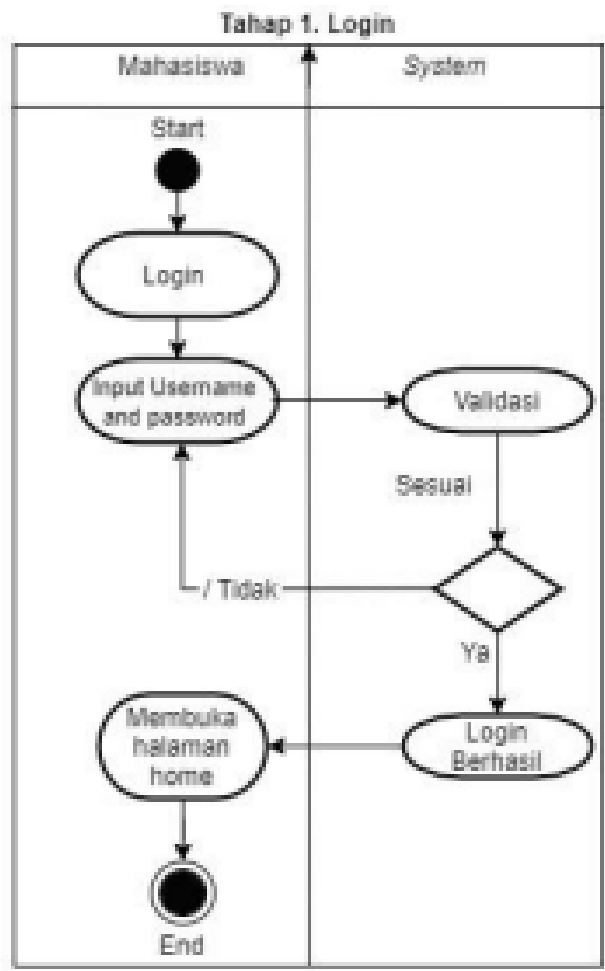

Tahap 2. Pendaftaran Beasiswa

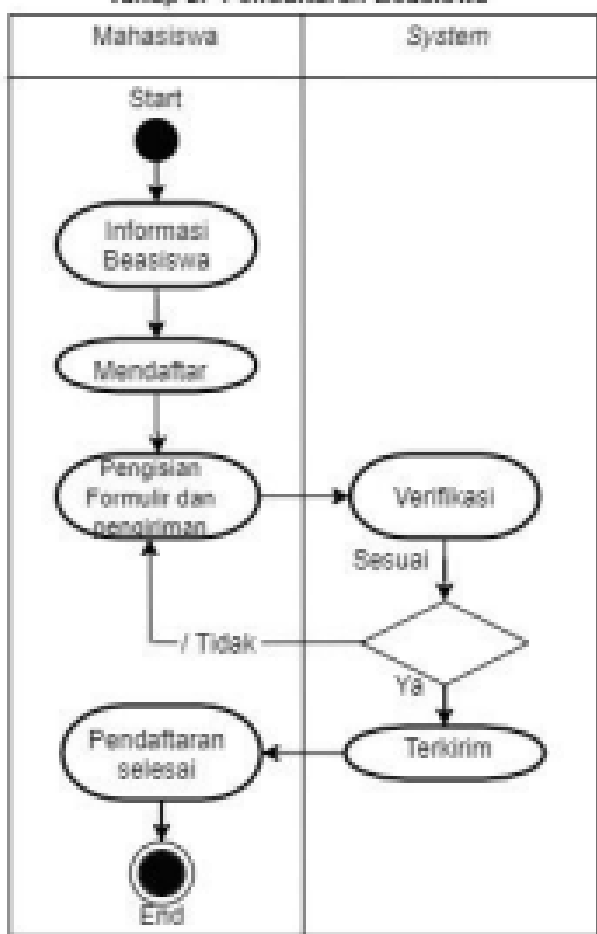

Tahap 3. Pengunguman Hasil Pendaftaran
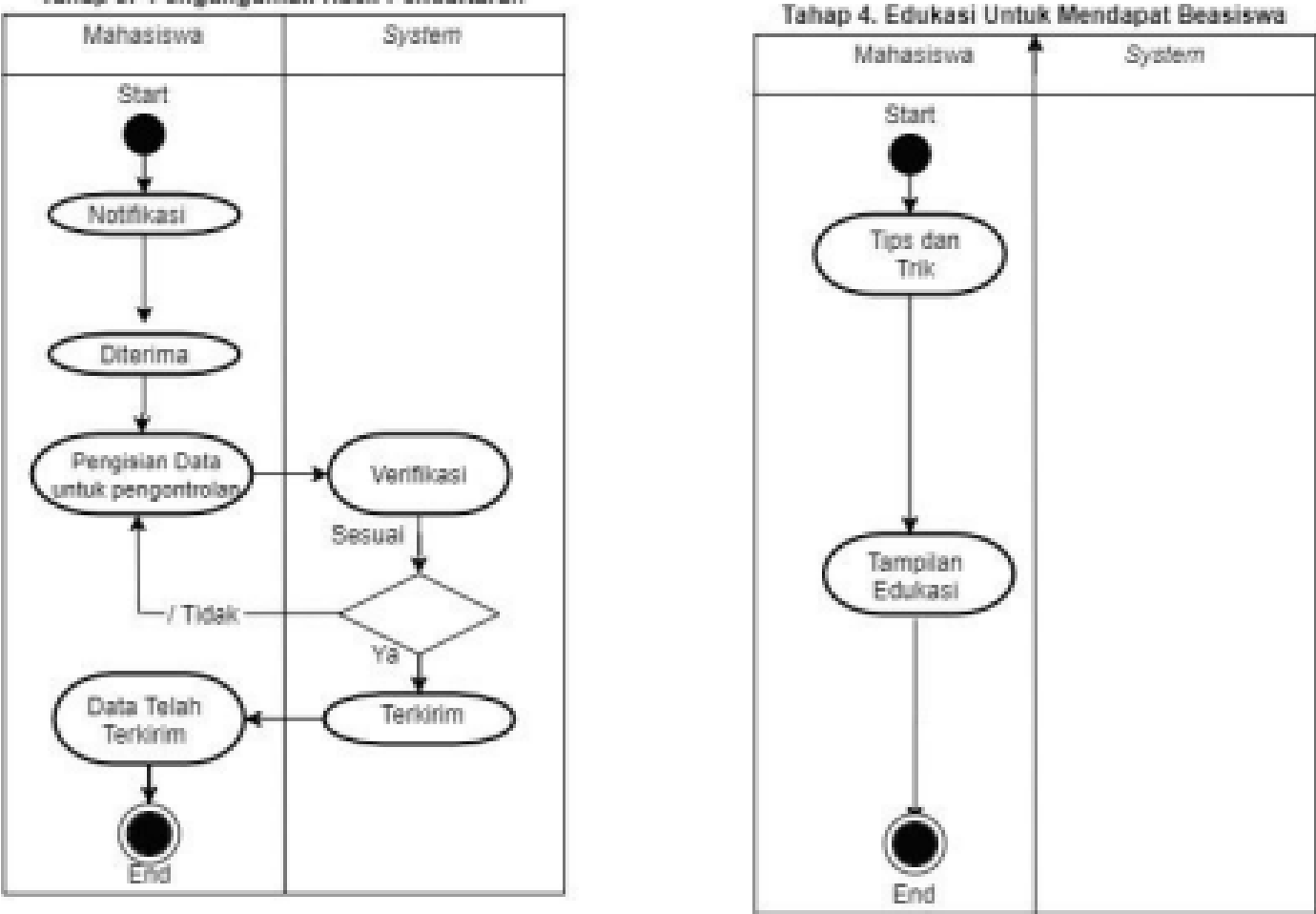

Gambar 4. Diagram Activity Mahasiswa 

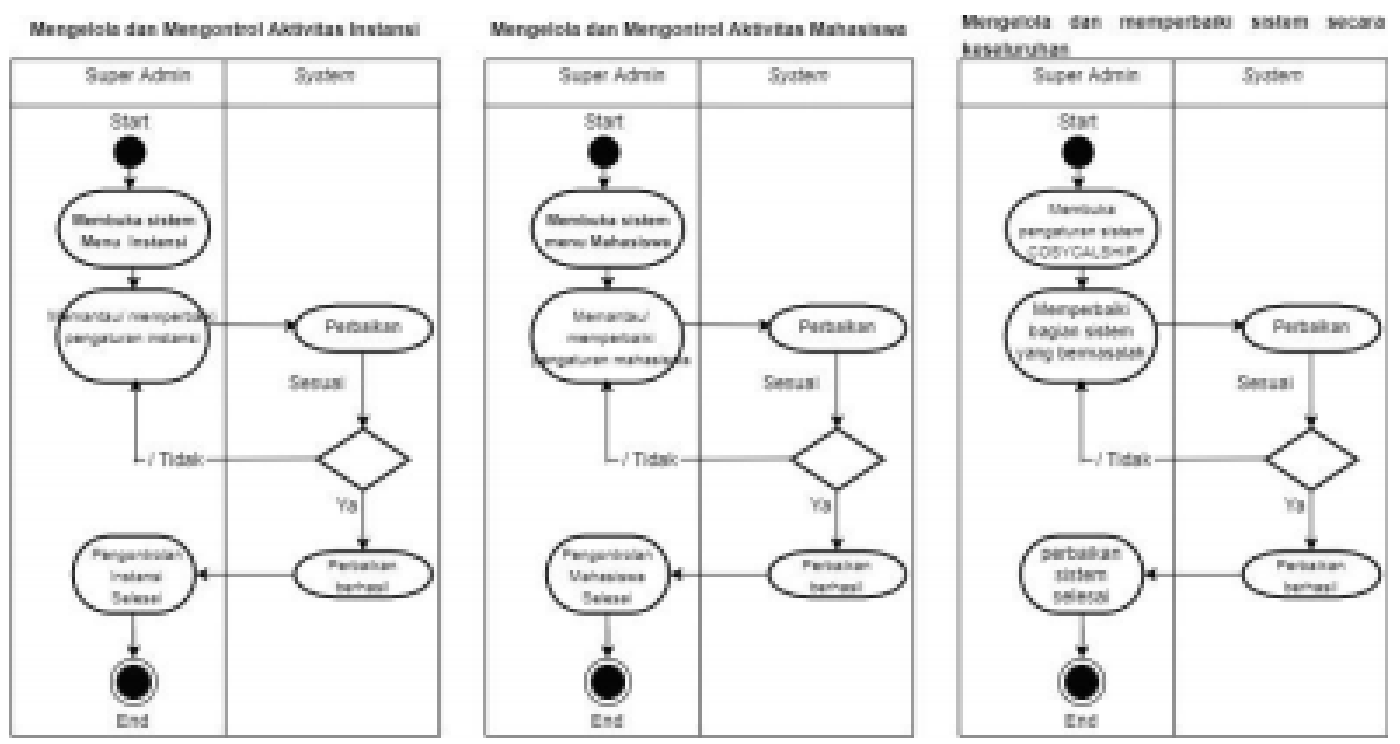

Gambar 5. Diagram Activity Super Admin

\subsection{Pemrograman}

Setelah melakukan design, tahapan selanjutnya adalah melakukan pemrograman pada sistem untuk menjadi aplikasi COSYCALSHIP, pemograman dilakukan menggunakan 21 PHP Hypertext Preprocessor yaitu bahasa pemrograman web server side yang bersifat open source atau gratis. 21 PHP Hypertext Preprocessor atau yang disebut PHP merupakan script yang menyatu dengan HTML dan berada pada server (server side HTML embedded scripting) (Kurniawan, 2010:2) bahasa pemrograman script yang paling banyak dipakai saat ini. Selain menggunakan PHP, juga diperlukan pemrograman Android, sehingga dapat mengimplementasi aplikasi COSYCALSHIP dengan baik.

\subsection{Mekanisme Kerja Aplikasi COSYCALSHIP}

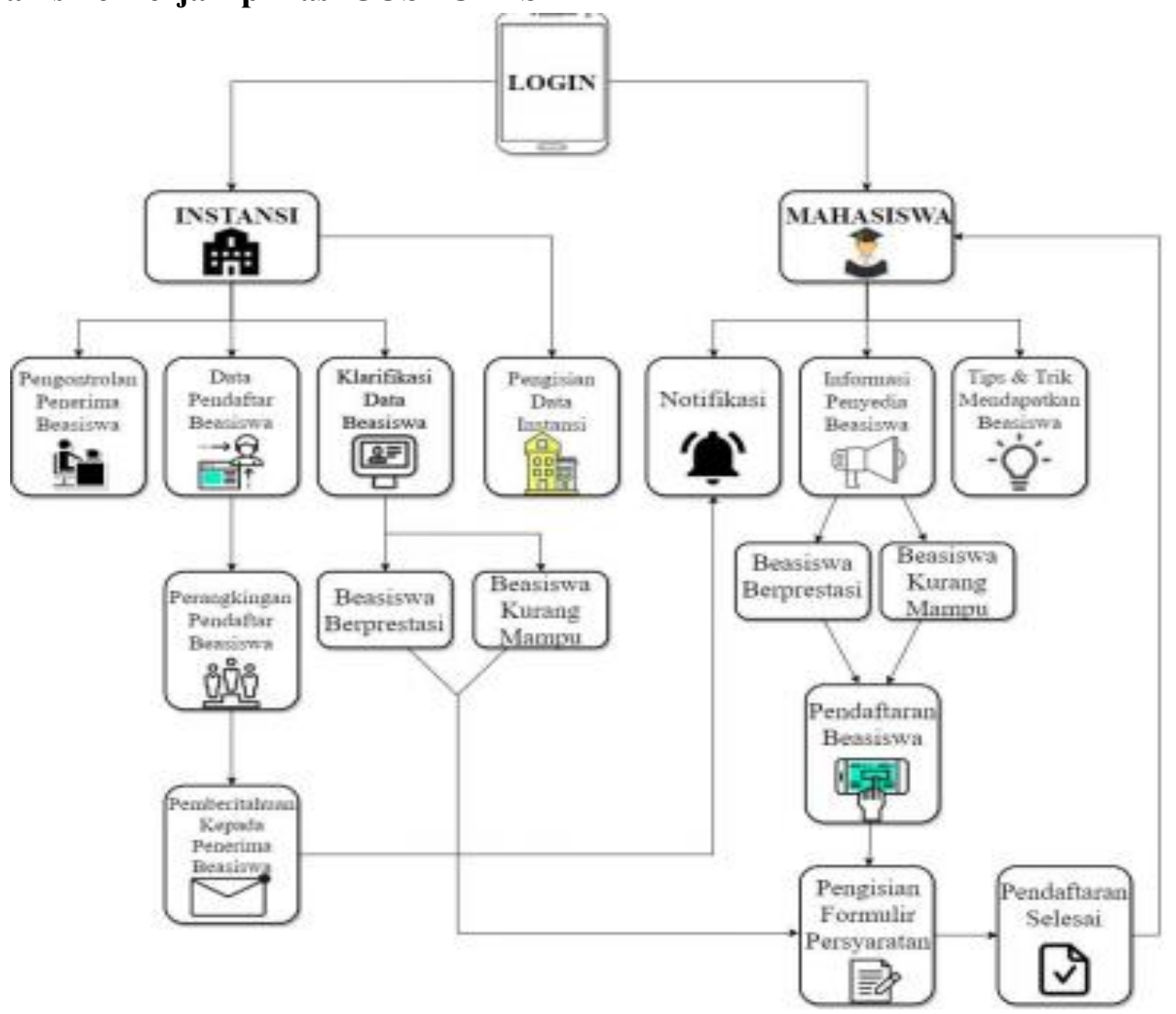

Gambar 6. Mekanisme Kerja Aplikasi COSYCALCALSHIP 
Berdasarkan gambar 6, mekanisme kerja aplikasi COSYCALSHIP adalah sebagai berikut:

1) Mekanisme kerja aplikasi COSYCALSHIP bagi instansi yaitu, proses yang pertama instansi harus login terlebih dahulu dengan menggunakan username dan password selanjutnya untuk instansi pemberi beasiswa harus memilih menu instansi dan setelah memilih menu tersebut nanti akan muncul empat menu yaitu yang pertama menu untuk pengisian data instansi itu sendiri. Kedua yaitu terdapat menu klasifikasi data beasiswa yang dimana data tersebut terdapat dua jenis yaitu beasiswa berprestasi dan beasiswa kurang mampu. Ketiga yaitu menu data pendaftar beasiswa, di dalam menu ini nantinya akan terdapat berbagai data pendaftar dan selanjutnya instansi akan melakukan perangkingan pendaftar beasiswa sesuai dengan ketentuan instansi pemberi beasiswa tersebut dan jika sudah melakukan perangkingan maka instansi tersebut akan memberikan pemberitahuan kepada penerima beasiswa ke masing-masing surel mereka. Menu yang keempat yaitu menu pengontrolan penerima beasiswa, menu ini nantinya akan berfungsi sebagai menu untuk mengontrol setiap kegiatan, perlombaan akademik maupun non akademik yang diikuti, dan nilai mahasiswa yang telah menerima beasiswa tersebut.

2) Mekanisme kerja aplikasi COSYCALSHIP bagi mahasiswa yaitu, mahasiswa harus login terlebih dahulu dengan menggunakan username dan password. Selanjutnya untuk mahasiswa mereka harus memilih menu mahasiswa, dimana di dalam menu mahasiswa tersebut terdapat tiga menu yaitu yang pertama menu tips dan trik mendapatkan beasiswa, di dalam menu ini akan terdapat tips dan trik mendapatkan beasiswa di instansi negeri maupun swasta. Menu yang kedua yaitu menu informasi penyedia beasiswa, pada menu ini akan terdapat informasi beasiswa yang terklasifikasi menjadi dua yaitu beasiswa berprestasi dan beasiswa kurang mampu, selanjutnya mahasiswa akan memilih beasiswa yang mana yang akan diambil setelah itu mahasiswa akan melakukan pendaftaran dimana syarat pendaftaran tersebut adalah harus mengisi formulir persyaratan, setelah mengisi formulir tersebut dengan lengkap dan benar maka pendaftaran telah selesai. Setelah itu terdapat menu notifikasi, pada menu inilah mahasiswa akan menunggu apakah mereka akan mendapatkan beasiswa atau tidak, pemberitahuan akan muncul pada surel masing-masing mahasiswa yang telah mendapatkan beasiswa dari instansi pemberi.

\subsection{Pengujian}

Proses pengujian menggunakan metode black box dibagi menurut fungsi dari masing-masing menu sesuai dengan kegunaannya. Bentuk pengujian berupa cara pengguna menggunakan aplikasi yang dapat dilihat pada tabel 2 .

\subsection{Manfaat Aplikasi COSYCALSHIP}

Manfaat yang akan dirasakan mahasiswa dan instansi dalam mengelola dan mencari informasi beasiswa melalui aplikasi ini yaitu sebagai berikut:

\subsubsection{Manfaat Bagi Instansi}

1) Melalui fitur klasifikasi penerima beasiswa pada menu instansi dapat membantu instansi dengan mudah menyalurkan beasiswa dengan tepat, cepat dan efisien yang sesuai dengan klasifikasi yang diinginkan baik itu beasiswa prestasi ataupun beasiswa kurang mampu.

2) Melalui fitur data pendaftar beasiswa, instansi secara sistematis dapat menyeleksi mahasiswa yang berhak menerima beasiswa dari dengan jumlah kuota yang dibutuhkan instansi. Sehingga memudahkan instansi dalam melakukan perangkingan hingga pengiriman informasi kepada mahasiswa yang berhak menerima beasiswa.

3) Melalui fitur pengontrolan beasiswa, instansi dapat dengan mudah mengontrol penerima beasiswa setiap semesternya, apakah prestasi dan kontribusinya untuk masyarakat semakin meningkat atau tidak, sehingga dapat mengetahui apakah mahasiswa tersebut layak/tidaknya menerima beasiswa dari instansi tersebut, jika selama pengontrolan terjadi penurunan, maka instansi dapat mencabut beasiswa dan diberikan kepada orang lain. 
Tabel 2. Pengujian Fasilitas/fitur dalam aplikasi

\section{Nama Pengujian}

\section{Bentuk Pengujian}

\section{Login}

Pengujian pengisian data

Pengisian data kualifikasi penerima beasiswa

Menu pemeringkatan pendaftar beasiswa

Pengujian menu pengiriman informasi penerima beasiswa

Pengujian menu kontrol kepada penerima Mengklik tombol menu pengontrolan beasiswa

Pengujian menu pengumuman

Pengujan menu edukasi
Memasukkan username dengan password

Menjalankan proses pengisian data pengajuan beasiswa

Menggunakan fasilitas pengisian data klasifikasi

Mengklik tombol pemeringkatan

Mengklik tombol pengiriman informasi kepada penerima beasiswa

Mengklik tombol pengumuman

Mengklik tombol pilih menu edukasi

\subsubsection{Manfaat Bagi Mahasiswa}

1) Melalui fitur data instansi pada menu instansi dan fitur informasi penyedia beasiswa pada menu mahasiswa yang saling terhubung, dimana saat instansi mengisi data mengenai beasiswa apa yang mereka sediakan, maka akan masuk fitur informasi penyedia beasiswa pada fitur mahasiswa, sehingga mahasiswa dapat dengan mudah memperoleh informasi penyedia beasiswa, serta dapat melakukan pendaftaran sesuai dengan klasifikasi yang disediakan instansi dengan cepat, dan mudah.

2) Melalui fitur notifikasi, dapat memudahkan mahasiswa memperoleh pemberitahuan/pengumuman dari instansi mengenai hasil pendaftaran beasiswa yang telah dilakukan.

3) Melalui fitur tips dan trik pada menu mahasiswa, dapat memberikan informasi dan edukasi kepada mahasiswa agar berhasil mendapatkan beasiswa.

\section{Kesimpulan}

Dari hasil analisis tentang pengembangan aplikasi COSYCALSHIP berbasis metode waterfall, maka dapat disimpulkan bahwa aplikasi COSYCALSHIP ini menggunakan metode waterfall dengan lima tahapan/fase yaitu fase analisis kebutuhan perangkat lunak, fase desain, fase pembuatan kode, fase pengujian, fase pendukung atau pemeliharaan. Metode ini memungkinkan untuk departementalisasi, control, dan proses pengembangan menggunakan model fase one by one sehingga dapat meminimalisir kesalahan yang mungkin dapat terjadi. Dan untuk desain aplikasi COSYCALSHIP terdiri dari deskripsi aktor/pengguna dan diagram activity dari aktor-aktor tersebut. Cara penggunaan aplikasi COSYCALSHIP, yaitu pengguna harus login pada menu instansi/mahasiswa terlebih dahulu. Pada menu instansi, pengguna dapat memilih empat fitur yaitu fitur pengisian data instansi, menu klasifikasi penerima beasiswa, data pendaftar beasiswa dan pengontrolan terhadap penerima beasiswa. Pada menu mahasiswa pengguna dapat memilih tiga fitur, yang terdiri dari fitur tips dan trik mendapatkan beasiswa, menu informasi penyedia beasiswa, dan fitur notifikasi hasil pendaftaran beasiswa. Melalui berbagai fitur dan menu dalam aplikasi COSYCALSHIP, mahasiswa akan lebih mudah memperoleh informasi penyedia beasiswa, melakukan 
pendaftaran beasiswa dan mendapatkan edukasi berupa tips dan trik untuk mendapat beasiswa. Sedangkan instansi akan lebih mudah, tepat dan cepat dalam mengelola beasiswa. Hal ini dikarenakan semua proses pengelolaan beasiswa yang terdiri dari klasifikasi beasiswa, pemeringkatan pendaftar beasiswa, pendataan terhadap penerima beasiswa serta pengontrolan terhadap penerima beasiswa akan dilakukan oleh sistem secara otomatis dalam aplikasi COSYCALSHIP.

\section{Daftar Pustaka}

Badan Pusat Statistik. [online]. https://www.bps.go.id/pressrelease/2020/08/05/1737/-ekonomiindonesiatriwulan-ii-2020-turun-5-32-persen.html/ (Diakses 5 Agustus 2020).

Badan Pusat Statistik. [online] https://www.bps.go.id/statictable/2009/04/16/972/pengangguranterbuka menurut-pendidikan-tertinggi-yang-ditamatkan-1986---2017.html/ (Diakses 13 Februari 2020).

Dermawan, J. dan Hartini, S. (2017). Implementasi model waterfall pada pengembangan sistem informasi perhitungan nilai mata pelajaran berbasis web pada Sekolah Dasar Al-Azhar Syifa Budi Jatibening. Paradigma, Vol. 19, No. 2, hal. 142-147.

Direktorat Penyusun APBN. [online] http://www.kemenkeu.go.id/media/13730/informasi-apbn2020.pdf / (Diakses 13 Januari 2020).

Hardiyan. (2017). Penerapan model waterfall pada program aplikasi pengolahan nilai siswa online pada SMP islam di Tangerang. Jurnal Techno Nusa Mandiri, Vol. XIV, (1).

Kementrian Riset, Teknologi, dan Perguruan Tinggi. (2018). Higher Educational Statistical Year Book". Pusat Data dan Informasi Ilmu Pengetahuan, Teknologi, dan Pendidikan Tinggi.

Kustian, N. (2019). Penggunaan model waterfall dalam pembuatan aplikasi pemesanan tiket bus. Satuan Tulisan Riset dan Inovasi Teknologi (String), Vol. 4, No. 1.

Nasution. (2012). Metode Reserch Penelitian Ilmiah. Bumi Aksara.

Pressman. R. S. (2010). Software Engineering: A Practioner's Approach. McGraw-Hill, New York.

Ridho, F. R. dan Soelistijadi, R. (2019). Perancangan aplikasi pemesanan makanan ringan berbasis object oriented dengan metode waterfall. Prosiding SENDI_U, hal. 277-284.

Sukamto dan Shalahuddin. (2013). Analisa dan Desain Sistem Informasi. Andi Offset, Yogyakarta.

Turban, E., Aronson, J., dan Liang, P. T. (2005). Decision Support Systems and Intelligent Systems (Sistem Pendukung Keputusan dan Sistem Cerdas) Jilid I. Edisi Bahasa Indonesia. Andi Offset, Yogyakarta. 